\title{
Narrator's Technique in the Iraqi Narrative Theater
}

"The Iraqi lay Baghdad of eternity between seriousness and humor as a symbol of Iraqi narrative the ater"

\author{
Assist. Prof. Dr. Najat E. Hassen \\ University of Baghdad \\ College of languages \\ German Department
}

\begin{abstract}
This article consists of four parts. The first part tries to clarify how the Arabs know the character of the narrator. It explains the importance of this character in literary works. Thus, it views the historical development of the narrator in the Arab world since the era before Islam, then in the era of Islam, and even the modern era. The second part talks about an Iraqi play who played a major role in the development of the Iraqi narrative art. It is Baghdad of eternity between seriousness and humor of the Iraqi dramaturge Qāsim Muhammad (1934-2009). This play was performed in Baghdad in 1974, where the narrator plays an important role in the narrative of theatrical events, as he connects the historical events that Iraq has experienced with the currently events of the Iraqi spectator. The third part views the epic features of Qāsim's play and tries to explain why this play was considered as new form of Iraqi theater. It is also want to know why the author used the heritage as a basic material for his play. At the same time this part wants to consider this play from another aspect, and views the real structure of it as new phenomenon at that time. All these will help us to know where the name of this play came from. The fourth part refers to the epic role of the narrator in Baghdad of eternity between seriousness and humor, in order to know more about this character and to view the important role that the narrator can play in the literary work. In addition this article discusses the dramaturges intention, which helps the spectator to meditate on the past and to learn from its lessons so that he can monitor his reality and criticizes it. It will explain why this character becomes a necessary part of the foundations and components of the dramatic work, such as text, author and heritage. Moreover this article will refer to Brecht's epic theater to find similarities between Brecht's theater and Qāsim's theater. Finally, it views the importance of Qāsim's play for the Iraqi society by preserving the literary heritage.
\end{abstract}

Keywords: Narrator; Narrative; Theater; Epic; Heritage; Literature; Eternity; Humor

\section{Introduction}

Our article consists of four parts. In the first part we try to clarify how the Arabs know the character of the narrator. It explains the importance of this character in literary works. Thus, this research views the historical development of the narrator in the Arab world since the era before Islam, then in the era of Islam, and even the modern era. The second part talks about an Iraqi play who played a major role in the development of the Iraqi narrative art. It is Baghdad of eternity between seriousness and humor of the Iraqi dramaturge Qāsim Muhammad (1934-2009). The play was performed in Baghdad in 1974, where the narrator plays an important role in the narrative of theatrical events, as he connects the historical events that Iraq has experienced with the currently events of the Iraqi spectator. The third part views the epic features of Qāsim's play and tries to explain why this play was considered as new form of Iraqi theater. It is also want to know why the author used the heritage as a basic material for his play. At the same time this part wants to consider this play from another aspect, and views the real structure of it as new phenomenon at that time. All these will help us to know where the name of this play came from. In the fourth part we refer to the epic role of the narrator in Baghdad of eternity between seriousness and humor, in order to know more about this character and to view the important role that the narrator can play in the literary work. In addition we discuss the dramaturges intention, which helps the spectator to meditate on the past and to learn from its lessons so that he can monitor his reality and criticizes it. We will know why this character becomes a necessary part of the foundations and components of the dramatic work, such as text, author and heritage. Moreover we will refer to Brecht's epic theater to find similarities between Brecht's theater and Qāsim's theater. Finally, this article views the importance of Qāsim's play for the Iraqi society by preserving the literary heritage.

\section{The Arab acquaintance with the narrator}

The Arabs have long been interested in the art of narration, even though the narrator has different names. For example, in Egypt called the narrator, Al-Samir and Al-Munšid. 
In Iraq it is called Al-Ḥakawātī and Al-Qaṣahūn. Al-Qașahūn is "an Arabic-Persian compound word and refers to the one who reads the narration orally or through a book." Al-Hakawātī is also the one who tells Al-Hikaya [narration] orally. But since when is the narrator known to the Arabs?

\section{A. At the time of the pre-Islam:}

The Arab narrator has been known to the Arabs, since the time of the pre-Islamic period. The critic Al-Selawie says: "The Hakawātīs migrated in the time of before Islam in the markets and consulting houses, where many people gather daily. They told them different stories that they had heard or witnessed." 2 Even current literary studies point to the "old tradition of depicting scenes from the narrative. In Mesopotamia, this tradition was revived during religious festivals. Since the scenes [from the narrative] only took place within the temples, they could not evolve."3 Al-Hakawātī of the pre-Islam took his stories "from the myths and reads it to his listeners verbally." According to Jawad Ali, "conflicts and disputes, myths and fairy tales dominated the stories of pre-Islam." a kind of prose. What supports our opinion that the narrative art is not foreign to the Arab people, is the fact that "the archaeologists and excavators found in the burial of the Sumerian and Babylonian civilizations literary tradition, which belongs at the beginning of the third millennium BC." 6 The Arab reader and viewer experienced a remarkable encounter with the narrator in Gilgamesh epic "1872." "This epic is the "oldest story in the world. Her hero was a historic king who lived in the Mesopotamian city of Uruk around 2750 BC." 8 And so this epic is older than the Bible and the Homeric Iliad. As the voice of God, which one hears but does not see, the narrator appears: "He had seen everything, had experienced all feelings, the most blissful and the most gloomy, had gained insight into the great mystery, the hidden places, the primeval days before the Flood, He had traveled to the edge of the world and had come back to work, but exhausted." Here the narrator tells us about Gilgamesh's ability to know everything, to have wisdom, and to tell us about the past and the future. And thus he wins the attention of his listeners. Therefore, the social and cultural living conditions played an important role in the development of Arabic narrative art. This development related to the storytelling of the narrators and to the themes of the stories. The evening census of the wandering Arabs gave a special meaning to narrative art. They talk about generosity, loyalty, audacity and courage. Therefore, we can say that the stories played a significant role in the lives of the Arabs of pre-Islam, even a social necessity.

\section{B. At the time of Islam:}

At the time of Islam, the situation of narrative art and thus also the places of narrators had changed. The narrators are here not only in certain consulting houses, but also in public places such as: Mosques, coffee houses and markets. In the month of fasting [Ramadan] e.g. the coffee houses are typical places for Al-Hakawātī: "They are considered as a resort and at the same time as an important "Station" for the narrator. The coffee shop visitors sit around, listen, smoke a water pipe and drink tea or coffee." ${ }^{10}$ During their free time, listeners listen to the Hakawātī in the cafe. AlHakawātī of coffee houses is characterized by the possibility that he can change his stories according to the reactions of the audience. Sometimes the audience forces him to put a happy end to the narrative. He himself will be a dramaturge; he changes the narrative and it's directing, and distributes the roles to the performers. The stories of the Hakawāti are sometimes religious themes, such as the life of the prophets and their life experiences.

\footnotetext{
${ }^{1}$ Al-'Atbaa, Mahmoud. 1963. "Al-Floklor in Bagdad" [Folklore in Baghdad]. Al-Aswaq Al-Tidjarya publishing house. Baghdad. P.55.

${ }^{2}$ Al-Selawie, Mohammed Adeeb. 1982. "Al-Iḥtifalya fi Al-Mesreh Al-Maġrabi Al-ḥadiț" [The festivity in the Modern Moroccan Theater]. Publications of the House of Cultural Affairs. Baghdad. P.39.

${ }^{3}$ Al-Zubaidy, Ali. 1966. "Al-Mesrehya Al-'Arabyafil'Iraq" [The Arab Drama in Iraq]. Al-Rissala publishing house. Baghdad. P.17.

${ }^{4}$ Ibid.

${ }^{5}$ Ali, Jawad. 1971. "Al-Mufeșel fi Tareeh Al-'Arab kabl Al-Eslaam" [Details of the history of Arabs of the Pre-Islam].Vol. 8. Dar Al-Ilm Lil malaeen. Beirut. P.34.

${ }^{6}$ Bakir, Taha. 1975. "MuqadamatMelhemet Gilgamesh" [Introduction of the epic Gilgamesh]. Publications of the Ministry of Information. Baghdad. P.9.

${ }^{7}$ See: Thrower, James. 1980. "The Alternative Tradition: A Study of Unbelief in the Ancient World". Mouton Publishers. The Hague. The Netherlands.

${ }^{8}$ Mitchell, Stephen (HRSG). 2006. "Gilgamesh. The primal myth of the king of Uruk and his Way of self-discovery". $1^{\text {st }}$ ed. GoldmannVerlag. Munich. P.9.

${ }^{9}$ Ibid. P.87.

${ }^{10}$ Awaad, Michael. 1962. "Alf Layla wa Layla Miraat Al-HaḍarawelMğteme' fil' Assr Al-Islami" [Thousand and One Nights. Mirror for Civilization and Society of Islam]. Publications of the Directorate of Arts and Folk Culture. Baghdad. P.3.
} 
Also in the holy book of Islam "The Koran" the role of the narrator was highly emphasized in order to spread the doctrine and instruction of the Islamic religion. This was openly stated in various verses of the Koran: "We narrate to you the most accurate history, by revealing to you this Quran. Although, prior to it, you were of the unaware." ${ }^{11}$ And elsewhere: "In their stories is a lesson for those who possess intelligence. This is not a fabricated tale, but a confirmation of what came before it, and a detailed explanation of all things, and guidance, and mercy for people who believe." $" 12$ In addition, in the Koran we find various passages where there were different narrators. Here are some passages: In verse 11 of Sura "Al-'Arāf", Allah assumes the role of the narrator: "We created you, then We shaped you, then We said to the angels, Bow down before Adam; so they bowed down, except for Satan; he was not of those who bowed down." " And in another verse, Adam takes on the task of the narrator: "They said, Our Lord, we have done wrong to ourselves. Unless You forgive us, and have mercy on us, we will be among the losers." ${ }^{14}$ In other verses, prophets also take the role of the narrator, such as "And God will say, O Jesus son of Mary, did you say to the people, 'Take me and my mother as gods rather than God?'“ He will say, "Glory be to You! It is not for me to say what I have no right to. Had I said it, You would have known it." ${ }^{15}$ Here we notice that these prophets, through their speech, have conveyed the speech of God; they are also mediators. Another image for the Hakawātī of Islam is found in the "religious preacher" whose function is to win the attention of his listeners to the lessons and wisdom of Islam. He reads and interprets stories from the Koran for his listeners and answers their questions. Then we realize that the narrator's job is not aimed only at enjoyment, but also at education.

\section{At the modern time:}

If one look at the Arab theater since the 19th century, one realizes that the pioneers of the Arab theatre, like e.g. Maroun An-Naqash (1817-1855), YusifIdris (1927-1991), Qāsim Muhammad (1934-2009) and others, were combined the traditional form of the Hakawātīs with the European form of the narrator in their literary works, in order to make the social and political conditions of the Arab world comprehensible to the Arab viewer. To pursue this aim, the Arab dramaturges used traditional coffee houses, folk Hakawātīs and popular milieu. There is a motive behind this that these dramaturges have intervened in the literary heritage in order to find themes that can represent their reality. The themes of their theater are derived from the Arab reality and its problems, embedded in a popular narrative, while at the same time they incorporate modernity into folklore, transforming theater into a social phenomenon. We find this exactly in the symbol of our article, namely in Qāsim's Baghdad of eternity between seriousness and humor (1974). This play consists of two parts and talks about the Iraqi society.

\section{The Iraqi play Baghdad of eternity between seriousness and humor as a symbol of the Iraqi narrative theatre}

Traders, coolies, sellers, shoppers, beggars, a poet and a narrator meet in a popular Baghdad market, chatting, arguing and having a colorful life. They're coming from different social classes. An Actor describe the real place of the play: "Dear audience, we are in a historical place. It is a traditional market of Baghdad in the time of the Arabic writer AmribnBahrr al-Ğāhiz." This market, so Actress 1, is "a real stage that is over a hundred years old." At that time "there were also many narrators." One of them "is the well-known narrator of Baghdad, Ibn Maqazeli", who will tell them "about seriousness and humor in Baghdad." The actors ask the audience, that they "in today's presentation should not asking for a specific story and not about beginning or end." Because "every figure represents a story, each scene represents a theme, and every word is a play." But IbnMaqazeli tell them later: "The story of Baghdad of eternity between seriousness and humor is a never-ending story. In Baghdad there used to be begging and poverty, but also prosperous life and luxury, rich princes and merchants." Here come three servants of the prince. Screaming, they announce the opening of the prince's newly-built garden, whose construction cost five million drachmas? A sad woman interrupt them whose husband killed from the prince's elephant during the construction of the garden, and say: "O Baghdad, your palaces are ruled by tyranny and inconsistency!" Revolutionaries coming on the stage: "Do not ignore the decent ones when they starve, nor the hungry when they get full! [Here enter the miser and the voracious Ascha'ab while beggars still beg]: "When will a law be passed to feed the hungry?" In the last scene, all actors are in a semicircle on the stage. While some of them explain the main idea of the presentation in a few sentences, the other actors take the role of a chorus: "Evil spreads everywhere. Nevertheless, there is also good.

\footnotetext{
11 The Quran. 2012. In the translation by TalalItani. Dallas. Beirut. Joseph-Sure. Verse 3. P.48.

12 Ibid. Joseph-Sure. Verse 111. P.89.

${ }^{13}$ Ibid. Al-'Arāf-Sure. Verse 11. P.53.

${ }^{14}$ Ibid. Verse 23. P.53.

${ }^{15}$ Ibid. Table-Sure. Verse 116. P.44. 
If you look around, you will not find anything except hunger and poverty, so you do not just have to open your eyes, but also the heart and the mind before it. The good thing lies in the heart of man. Anyone looking for it will find her." The narrator turns to the audience: "Dear viewers, I hope you are satisfied with this presentation full of contradictions of seriousness and humor."16

\section{[Applause of the audience]}

\section{The epic features of Baghdad of eternity between seriousness and humor}

When this play was played in Baghdad in 1974, it marked a new phenomenon in Iraqi theater, be it through its structure or its revival of Arab tradition. But no literary criticism pointed to whether this play was similar to the epic theater. That's why we want to look at this play from a special aspect. If we look at the German epic theater of Bertolt Brecht (1898-1956), we realize that Qāsim Muhammad was influenced by this theater. After Qāsim Muhammad graduated from the Institute of Fine Arts in Baghdad in 1962, he went to the Soviet Union to study directing. This gave him the opportunity to "deepen his acquaintance with Brecht's theater and recognize the importance of tradition in theater development. ${ }^{, 17} \mathrm{He}$ was not only a director and actor, but also a writer. Brecht's influence on him confessed Qāsim himself: "Brecht supported the open plot of a drama and I as an artist accept such theater more than the classical theater, which is characterized by the principle of the three units. Because, this theater can represent the big world in a few hours." ${ }^{\prime 18}$ Noteworthy means the open plot of a drama: "the renunciation of a dramatic ending [...], as an alternative to the closed drama." 19

A. It is divided into independent scenes. Each scene represents a specific everyday theme.

B. The events of the play are represented by different characters. They took place in one place [ancient market]. Daily happen in these market events that represent all the contradictions of life.

C. Each character has its own story and its own characteristics and acts on two levels; a so-called folkloric level on which the figure adheres to its traditional role and preserves its traditional characteristics as the basis of its behavior, and a contemporary level in which the figure is considered part of the present and its problems.

D. In order to put the audience in the role of a viewer, Qāsim Muhammad had placed some chairs in the auditorium. This will make the audience part of the action being played. In addition, the changing of lighting was a part of the presentation.

F. As another method of breaking the fictitious fourth wall, the author let actors sit in the auditorium in order to find a connection between the audience and the stage. At the same time, the actors occasionally turn to the audience for a direct contact with him.

G. Qāsim Muhammad was used another means of epic theater by putting on stage a popular narrator [Hakawātī] who not only narrates but also comments on and explains events. As he reads stories full of old-time experiences, he comments on the events and asks his public about it. He lets the audience learn lessons from the old events, so they can learn from them. Thus, his narrative is a mixture of the events of the story and the events of the present reality on the stage, also the reactions and wishes of the audience to the narrative.

H. In Baghdad of eternity between seriousness and humor the author emphasizes the role of the viewer by encouraging his participation in the transformation of society. This reached the author by his criticism of the rich people, who increase their wealth at the expense of the poor people. The rich have piles of money, while the poor have only humor and jokes. This allows the viewer to search for the reasons behind the riches of the rich and the poverty of the poor.

Therefore Baghdad of eternity between seriousness and humor can be considered a significant step in the development of Iraqi theater at the time, because it not only used a popular Hakawātī and renounced the classical trinity, but because it examined the heritage, to represent the Iraqi reality through the theater.

\section{The epic role of the narrator in Baghdad of eternity between seriousness and humor}

When we consider the narrator in Qāsims play, we realize that the narrator [Al-Hakawātî] acts on two levels:

1. The Time of the story [Hakawātī on the Market]

2. The time of the present reality in which the narration is told. [On stage, so in the present]

\footnotetext{
${ }^{16}$ Muhammad, Qāsim. 1974. "Baghdad of eternity between seriousness and humor". Manuscript. Baghdad. P.10-97.

${ }^{17}$ Ğalūd, Zāfir. 1986. Al-Talia`a Al-`Arabiya 179. ed. Okt. Paris. P.46.

18 Ibid.

${ }^{19}$ Pfister, Manfred. 2001. "The drama. Theory and analysis". 11. ed. W. Fink UTB publishing house. P.322.
} 
Here the Hakawātī is like the epic narrator and has various epic roles; On the one hand, he is a witness to the events of the story, on the other hand, he take the role of the observer and critic, such as "This is Al-Kindi ... He was a very stingy man and had a house" 20 , and in "Evil is too much and good is not enough. That is why we want to arouse your thinking with this representation." 21 At the same time he stays away from the events which played by telling only without interfering. Here he helps to follow the event and comment on it. And therein lies the peculiarity of epic theater, namely the narrative accompaniment of events.

In addition, Al-Hakawātì sometimes turns to the audience and talks to him, "And every beggar went off to put on the clothes of his characters." 22 In doing so, he tries to make the audience into a good observer so that he can comment and criticize the depicted action on the stage. This method could prevent any dramatic identification. This is exactly what Brecht's theater aimed for. For Brecht's audience, the action on the stage would have to be "transparent" and "controllable from the experience of the audience."23

Moreover, Al-Hakawātî intends to arouse the curiosity of the listeners by giving them rest periods to reflect on the narrative, and mention their comments on it, which relies on the excitement of the listener's interest. This creates a direct participation between the listener and the narrator. That's why we can consider Al-Hakawātî's audience an active audience; he stirs, comments and interferes. Brecht considered this active participation of the audience in the presented event as a "legal case for a decision." 24

Another method of preventing the dramatic illusion that the author has brought in Baghdad of eternity between seriousness and humor is his benefited from the Arab tradition. He said: "The revival of the Arab and especially the Iraqi folk tradition is helping to found a purely Iraqi theater ... and this is important to distinguish Arab theater from other world theaters." ${ }^{25}$ So QāsimMuhammad reviewed the Arab tradition to find a dramatic narrative material for an Iraqi folk drama involving wisdom and instruction. With this play, the Iraqi theater of the seventies experienced a moving event, which had used the theater as a means to revive the heritage. Therein, the theater critic Lamic Al-Amari sees "a new artistic value. Because such a play supports an essential theme in the Arab theater area, namely how to revive the tradition in the current plays. ${ }^{, 26}$ We agree with that, because this method can focus on the purely Arab identity of Iraqi theater. That's why Qāsim's theater marked social necessity in the 1970s. These years were shaped in Iraq by the yearning of people for social change. This is exactly what the author of Baghdad of eternity between seriousness and humor emphasized: "I believe in the importance of social change and see the theater as one of the means to get this change."27

Not only the narrator and the tradition has let this play prevent the viewer from identifying with the represented events, but also the destruction of the Aristotelian trinity. This is what the actors of the play have revealed to the audience:

"Actress 2: The stories of Hakawātī are part of our present reality. But the difference between the both is 1000 years.

Actress 1: But in our today's presentation, you're not asking for a specific story.

Actor 1: And not for especially theme.

Actress 2: And after no beginning or end. ${ }^{, 28}$

Since Qāsim Muhammad has in his works mostly combined the "old" folk tales with the problems of Arab reality, his narrative art can be seen as a vent for Arab society, especially when his narratives talk about everyday life and criticize it. In addition, his plays prove that he has combined Brecht's concepts with the Arabic folk tradition to create a new folk theater that not only entertains but also teaches. Through Baghdad of eternity between seriousness and humor he wanted to revive the tradition of Hakawātīs, so that the audience can think along, participate and comment. Bertolt Brecht emphasized this in his theater earlier. The Iraqi author wanted to preserve tradition and folk culture through his extraction from the inheritance while getting to know the culture of others. He also wanted to found a new non-classical Iraqi theater.

\footnotetext{
${ }^{20}$ Muḥammad, Qāsim. 1974. Ibid. P.19.

${ }^{21}$ Ibid. P. 97.

${ }^{22}$ Ibid. P.63.

${ }^{23}$ Benjamin, Walter. 1982. "What is the epic theater?" In: Collected writings. Part 2, edited by Rolf Tiedemann and Hermann Schweppenhäuser. Suhrkamp, Frankfurt/ Main. $2^{\text {nd }}$ ed. P.344.

${ }^{24}$ Hinck, Walter. 1971. "The dramaturgy of the late Brecht". In: Reinhold Grimm. "Epic Theater". Cologne

(Kiepenheuer\&Witsch), ISBN 3-462-00461-1. P.74.

${ }^{25}$ Al-'Ateebee, Hussein.1972. "Aț-tiqafawelMesrehwelTuraț" [The culture, the theater and the tradition]. Al-Yaqaḍa Magazine. 270 ed. Aug. Kuwait. P.6.

${ }^{26}$ Al-Amari, Lamic. 1981. in magazine "MawaqefAdabya" 127. P.55.

${ }^{27}$ A conversation with the author in the magazine "MawaqefAdabya". Ibid. P.59.

${ }^{28}$ Muhạmmad, Qāsim. 1974. Ibid. P.9. 


\section{Conclusion}

Baghdad of eternity between seriousness and humor was based on stories from popular tradition, which have not only entertainment, but also teaching and wisdom. They emphasize the role of human beings in changing society and encourage their participation in it. The author combined this tradition with the present by letting his Hakawāti tell the audience stories from the past, which were then presented by the actors. So, the author aims to allow the current viewer to take a lesson from the past. This method enabled his Hakawātī to be a historical and contemporary narrator. And of that came, as we think, the name of the play Bagdad of eternity between seriousness and humor, whose "colorful" figures represent a "colorful" society. This colorful society and its colorful events made this play for "eternal". The question; why did Qāsim Muhammad fall back on the Arab heritage can we answer:

1. Because the Arab tradition is not only a source of narrative and tales, but is full of theories and wisdom. Tradition gives Arab authors the opportunity to combine their suffering and fear with the hope of a better future.

2. Tradition allows Arab dramaturges to see the contradictions of their reality in the experience of tradition. This is precisely what we can attribute to one reason, namely that they do not want to trigger a revolution, but to arouse the critics of the viewer. The author could achieve this on the condition that he keeps a distance between his reality and the tradition. That is why we can regard the relationship of the past to the present and the future as a dialectical relationship. For the past reflects the present, from which the future can be influenced. This connection is not a mere connection of a human being with history, but a longing for the lost, beautiful reality.

With his Baghdad of eternity between seriousness and humor Qāsim Muhammad wants to prove that heritage helps:

A. To give an artistic value to the theater performance, such as a cultural identity.

B. To reflect the society and its current problems through the past.

C. To politicize the theater in order to convey political ideology through theater performances.

Qāsim Muhammad used a historical narrator, which is called "Hakawātī" in the Arab world. This Hakawātī can be considered a popular "version" of today's narrator. He has the opportunity to influence the others through his rhetoric. As he talks, he uses poetry, songs, facial expressions and gestures to fascinate his listeners and lay down the fourth wall. Therefore, one can regard the "Hakawātī phenomenon" as a historical phenomenon that has evolved through the history of Arab literature development. In the Arab world, the mosques and consulting houses were the first stations for the figure of Hakawātīs. Even the "phenomenon" of Al-Hakawātì builds a bridge between the past and the present, which deserves special attention to improve the current narrative situation. Al-Hakawātî is highly talented and able to present his story in an interesting and fascinating way. Through his real everyday narratives and his simple stage of popular coffeehouses, he became part of the real reality that can be seen on the one hand as a means of pleasure and on the other as a means of instruction. In an indirect way, he teaches the audience in an interesting way, telling stories of good and evil, and always winning the good. These stories are not simple stories, but stories that teach and have meaning. Through his narrative, Al-Hakawātī seeks to emphasize the morality of Arab society. That's why we can think of his job as a teaching profession.

In addition Qāsim Muhammad used the theater as a means of realizing social change. He succeeded in revealing the contradictions of life by creating a colorful society on stage; Rich, poor, nobles and swindlers had shown so that the audience can know his own society in which he lives better. He also brought in his play historical themes from the Iraqi heritage, the interpretations of the reality of the presentation time and their political problems, such as: social injustice, tyranny of leaders, class struggle and others. The reason is, as we think, not only to encourage people to talk about politics, but also to emphasize the Arab countries' struggle for democracy as an essential theme of the 1970s.

\section{References}

Al-'Atbaa, Mahmoud: Al-Floklor in Bagdad [Folklore in Baghdad]. Al-Aswaq Al-Tidjarya publishing house. Baghdad. 1963.

Al-'Ateebee, Hussein: At-tiqafawelMesreḥwelTurat [The culture, the theater and the tradition]. Al-Yaqaḍa Magazine. Ed.270. Aug. Kuwait. 1972.

Al-Selawie, Mohammed Adeeb: Al-Iḥtifalya fi Al-Mesreh Al-Maġabi Al-hadit [The festivity in the modern Moroccan theater]. Publications of the House of Cultural Affairs. Baghdad. 1982.

Ali, Jawad: Al-Mufeșel fi Tareeh Al-'Arab kabl Al-Eslaam [Details of the History of the Arabs of the Pre-Islam]. Vol. 8. Dar Al-Ilm Lil malaeen. Beirut. 1971.

Al-Zubaidy, Ali: Al-Mesrehya Al-'Arabyafil'Iraq [The Arab Drama in Iraq]. Al-Rissala publishing house. Baghdad. 1966. 
Awaad, Michael: Alf Layla wa Layla Miraat Al-HaḍarawelMğteme' fil 'Assr Al-Islami [Thousand and One Nights. Mirror for Civilization and Society of Islam]. Publications of the Directorate of Arts and Folk Culture. Baghdad. 1962.

Bakir, Taha: MuqadamatMelhemet Gilgamesh. [Introduction of the epic Gilgamesh]. Publications of the Ministry of Information. Baghdad. 1975.

Benjamin, Walter: What is the epic theater? In: Collected writings. Part 2. Edited by Rolf Tiedemann and Hermann Schweppenhäuser. Suhrkamp. Frankfurt/ Main. 2nd Ed. 1982.

Ğalūd, Zāfir: Al-Talia`a Al-'Arabiya 179. Oct. Paris. 1986.

Hinck, Walter: The dramaturgy of the late Brecht. In: Reinhold Grimm: Epic Theater. Cologne (Kiepenheuer\&Witsch). ISBN 3-462-00461-1. 1971.

Kamal El Deen, Mohammed: Al-'Arab WelMesreh [The Arabs and the Theater]. Cairo. Dar el Hilal- Publishing House. 1975.

Mitchell, Stephen (HRSG): Gilgamesh. The primal myth of the King of Uruk and his way of self-discovery.1.Ed. Goldmann-Publishing House. Munich. 2006.

Mittenzwei, Werner (Ed.): Brecht's Plays II. 1.Ed. Aufbau-Publishing House. 1973.

Muhmmad, Qāsim: Baghdad of eternity between Ernst und Humor. Baghdad. Manuscript. 1974.

Muḥmmad, Qāsim: A conversation with him in the magazine "MawaqefAdabya". 127. 1981.

Pfister, Manfred: The drama. Theory u. Analysis. 11. Ed. W.Fink UTB Publishing House. 2001.

Wilpert, Gero von: Sachwörterbuch der Literatur. Alfred Kröner Publishing House. Stuttgart. 1969.

The Koran: In the translation by TalalItani. Dallas. Beirut. 2012. 